\title{
PENINGKATAN HASIL BELAJAR SISWA MELALUI STRATEGI PEMBELAJARAN DISCOVERY PADA MATA PELAJARAN IPA BIOLOGI KELAS VII-5 SMPN 4 MATARAM
}

\author{
Mahyaeny \\ Guru IPA SMPN 4 Mataram, Kota Mataram, Nusa Tenggara Barat \\ Email : mahya.yeni@yahoo.com.
}

\begin{abstract}
Abstrak: Telah dilakukan penelitian menggunakan strategi pembelajaran discovery pada mata pelajaran IPA Biologi Kelas VII-5 SMPN 4 Mataram untuk meningatkan hasil belajar siswa. Penelitian dilaksanakan secara kolaboratif antara guru mata pelajaran dengan teman sejawat dalam bentuk penelitian tindakan kelas. Penelitian ini melibatkan siswa kelas VII-5 sebanyak 32 orang. Penelitian dilakukan dalam 2 siklus, masing-masing siklus terdiri dari tahap perencanaan, pelaksanaan tindakan, observasi, evaluasi, dan refleksi. Keberhasilan dalam penelitian ini tercapai apabila ketuntasan belajar klasikal $\geq 85 \%$ dan $K K M \geq 60$. Selain itu indikator keberhasilan pelaksanaan strategy pembelajaran discovery jika hasil observasi memperoleh rata-rata skor $\geq 4,5$ (sangat memuaskan). Hasil penelitian menunjukkan bahwa hasil belajar siswa pada siklus I adalah rata-rata kelas 71,8. Siswa yang memenuhi ketuntasan belajar individu sebanyak 21 siswa dari 32 siswa, sehingga presentase ketuntasannya mencapai $66 \%$. Rata-rata skor pelaksanaan pembelajaran dengan strategi discovery 3,85 (memuaskan). Pelaksanaan evaluasi pada siklus II diperoleh data hasil belajar siswa dengan rata-rata 82,2. Presentase ketuntasan belajar secara klasikal mencapai 90\%. Rata-rata skor pelaksanaan pembelajaran dengan strategi discovery 4,86 (sangat memuaskan). Kesimpulan dari penelitian ini adalah penerapan strategi pembelajaran discovery dapat meningkatkan hasil belajar IPA Biologi siswa kelas VII-5 SMPN 4 Mataram.
\end{abstract}

Kata-kata Kunci : Hasil belajar, Discovery, IPA Biologi

\begin{abstract}
Research using discovery learning strategies on the subjects of biology in grade VII-5 SMPN 4 Mataram has been done to improve student learning outcomes. The research was conducted collaboratively between teachers and peers in the form of classroom action research. The study involved students of class VII-5 as many as 32 people. The study was conducted in two cycles, each cycle consisting of planning, action, observation, evaluation, and reflection. This study was classical learning completeness succeed if $\geq 85 \%$, and the minimum completeness criteria $\geq 60$. In addition, the successful discovery learning is indicated resources by an average score of $\geq 4.5$ (very satisfactory). The results showed that the learning outcomes in the first cycle is an average grade 71.8. Students who meet the individual learning completeness as many as 21 students from 32 students, so the completeness percentage reached $66 \%$. The average score of the implementation of learning by discovery strategy 3.85 (satisfactory). In the second cycle learning outcomes of students obtained an average of 82.2 and the classical learning completeness percentage reached $90 \%$. The average score of the implementation of learning by discovery strategy 4.86 (very satisfactory). The conclusion was that the application of discovery learning strategies can improve student learning outcomes in class VII-5 SMPN 4 Mataram.
\end{abstract}

Key words: Learning achievement, Discovery, Biology Science

\section{PENDAHULUAN}

Sesuai dengan UU no. 20 tahun 2003 tentang sistem pendidikan nasional pasal 3 menyatakan bahwa pendidikan nasional berfungsi mengembangkan kemampuan dan membentuk watak serta peradaban bangsa yang bermartabat dalam rangka mencerdaskan kehidupan bangsa, bertujuan untuk berkembangnya potensi peserta didik agar menjadi manusia yang bertaqwa kepada Tuhan Yang Maha Esa, berakhlak mulia, sehat berilmu, cakap, kreatif, mandiri dan menjadi warga Negara yang demokratis serta bertanggung jawab.

Dengan memperhatikan isi dari UU no. 20 tahun 2003 tersebut maka tugas seorang guru memang berat sebab kemajuan suatu bangsa ditentukan oleh keberhasilan pendidikan dari bangsa itu sendiri [1]. Peran guru adalah sebagai sumber belajar fasilitator, pengelola, demonstrator, pembimbing dan evaluator. Sebagai motivator guru harus mampu membangkitkan motivasi siswa agar aktivitas belajar siswa dalam proses belajar berhasil dengan baik. Salah satu cara dalam membangktkan aktivitas siswa dalam proses belajar adalah dengan menggunakan strategi pembelajaran kooperatif dimana siswa mampu menggali sendiri, memecahkan sendiri masalah-masalah dari suatu konsep yang dipelajarinya [2].

Strategi pembelajaran yang dilakukan guru di SMPN 4 Mataram masih didominasi oleh peran guru (teacher centered). Metode ceramah dan tanya jawab selama ini masih dominan dilakukan. Guru lebih banyak menempatkan siswa sebagai objek bukan sebagai subjek didik. Pendidikan seperti dirasakan masih kurang memberikan kesempatan kepada siswa untuk mengembangkan kemampuan berpikir holistic (menyeluruh), keatif, objektif, dan logis. Sebagai dampak dari hasil tersebut, maka hasil belajar siswa masih jauh dari harapan. Hal ini dapat 
dibuktikan dari hasil ulangan harian siswa seperti terlihat pada tabel di bawah ini.

Hasil Observasi nilai mata pelajaran IPA Biologi untuk kelas VII 4-7 siswa yang tuntas belajar atau nilainya di atas atau sama dengan KKM (60) dapat dilihat pada tabel 1 berikut:

Tabel 1: data KKM siswa kelas VII 4-7

\begin{tabular}{cccc}
\hline No. & Kelas & KKM & $\begin{array}{c}\% \\
\text { Ketuntasan }\end{array}$ \\
\hline 1 & VII-4 & 60 & 74 \\
2 & VII-5 & 60 & 62 \\
3 & VII-6 & 60 & 68 \\
4 & VII-7 & 60 & 65 \\
\hline
\end{tabular}

Sebelumnya peneliti pernah menggunakan model model pembelajaran kooperatif tipe TPS (Think Pair Share) untuk meningkatkan aktivitas belajar IPA Biologi siswa Kelas VIII.5 SMPN 4 Mataram dengan hasil yang cukup baik [3]. Namun sebagai pembanding maka perlu dilakukan aplikasi menggunakan pendekatan lain seperti pendekatan discovery. Hasil penelitian sebelumnya tentang penggunaan discovery menunjukkan bahwa siswa yang terlibat dalam pembelajaran dengan pendekatan discovery memperoleh prestasi IPA Biologi yang lebih baik [4-5].

Strategi pembelajaran memiliki peran yang sangat penting dalam meningkatkan hasil belajar siswa. Penerapan strategi pembelajaran yang tepat dan sesuai dengan situasi dan kondisi siswa dapat membantu guru dalam menyampaikan materi pelajaran sehingga tujuan pembelajaran dapat tercapai. Melalui pembelajaran dengan menggunakan strategi pembelajaran discovery akan terjadi pembelajaran yang mengaktifkan siswa dalam menemukan fakta, konsep dan prinsip yang ada dalam materi pembelajaran. Selama pembelajaran berlangsung, siswa saling berbagi ide (pendapat) sehingga dapat meningkatkan daya nalar dan kreativitas berpikir siswa. Setiap siswa akan terlibat dalam pembelajaran dan memberikan kesempatan pada semua siswa untuk menyampaikan temuannya. Dengan demikian, pembelajaran discovery dapat menciptakan suasana belajar yang kondusif untuk menemukan dan menyelesaikan tugas-tugas pembelajaran dengan lebih aktif dan kreatif. Selain itu siswa dapat melakukan interaksi social, berdiskusi dengan temannya untuk menemukan jawaban dari tugas yang diberikan dan bertanggung jawab untuk menjelaskan hasil temuannya kepada siswa lain. Sehubungan dengan hal tersebut, siswa dilatih untuk dapat menemukan sendiri dari permasalahan yang diberikan dengan berpikir aktif, kreatif dan bertanggung jawab. Melalui proses ini diharapkan dapat meningkatkan daya pikir, aktivitas, kerjasama dan tanggung jawab sehinggga dapat memberikan kontribusi terhadap meningkatnya pemahaman dan hasil belajar siswa. Discovery merupakan strategi pembelajaran yang berpusat pada siswa, melibatkan lebih banyak proses mental siswa seperti mengamati, menjelaskan, mengelompokkan, membuat kesimpulan dan sebagainya yang pada gilirannya dapat meningkatkan hasil belajar [6].

Proses belajar mengajar perlu berkualitas karena proses belajar mengajar merupakan inti dari kegiatan pendidikan di sekolah agar tujuan pendidikan dan pengajaran berjalan dengan benar maka perlu proses belajar mengajar yang berkualitas mulai dari merencanakan pelajaran sehari-hari, mengembangkan materi, menentukan strategi, metode yang cocok dengan materi dan kondisi siswa serta mengevaluasi kegiatan belajar mengajar [7].

Strategi Discovery dapat mengalihkan kegiatan belajar mengajar dari situasi yang didominasi guru ke situasi yang melibatkan siswa dalam proses mental melalui penemuan [8]. Strategi discovery merupakan strategi belajar mengajar yang melibatkan siswa secara maksimal dalam usaha mencari dan menemukan informasi. Strategi ini merupakan cara penyajian pelajaran yang banyak melibatkan siswa dalam proses-proses mental dalam rangka penemuannya. Proses mental, misalnya; mengamati, menjelaskan, mengelompokkan, membuat kesimpulan dan sebaaginya.

Strategi discovery menempatkan guru sebagai fasilitator, guru membimbing siswa dimana ia diperlukan, siswa didorong untuk berpikir sendiri, sehingga dapat "menemukan" prinsip umum berdasarkan bahan atau data yang telah disediakan oleh guru. Sampai seberapa jauh siswa dibimbing, tergantung pada kemampuannya dan materi yang sedang dipelajari. Dengan strategi ini, siswa diharapkan kepada situasi bebas menyelidiki dan menarik kesimpulan. Terkaan, intuisi dan mencoba-coba (trial and error) hendaknya dianjurkan. Guru bertindak sebagai penunjuk jalan, membantu siswa agar mempergunakan ide, konsep, dan keterampilan yang sudah mereka pelajari sebelumnya untuk mendapatkan pengetahuan yang baru. Pengajuan pertanyaan yang tepat oleh guru akan merangsang kreativitas siswa dan membantu mereka dalam "menemukan" pengetahuan baru tersebut [2].

$$
\text { Strategi discovery memang }
$$

membutuhkan waktu yang relatif banyak dalam pelaksanaannya, akan tetapi hasil belajar yang dicapai sebanding dengan waktu yang digunakan. Pengetahuan yang baru akan melekat lebih lama apabila siswa dilibatkan secara langsung dalam proses pemahaman dan "mengkonstruksikan" sendiri konsep atau pengetahuan tersebut. Model ini dilakukan baik secara perorangan maupun kelompok [9].

Menurut Sutrisno [10] agar pelaksanaan strategi discovery berjalan dengan efektif, beberapa 
langkah yang harus diperhatikan oleh guru adalah sebagai berikut: merumuskan masalah yang akan diberikan kepada siswa, yang dinyatakan dengan pernyataan dan pertanyaan. Perumusan harus jelas, hindari pernyataan yang menimbulkan salah tafsir sehingga arah yang ditempuh siswa tidak salah. Konsep atau prinsip yang harus ditemukan siswa melalui kegiatan tersebut perlu ditulis dengan jelas, diskusi sebagai pengarahan sebelum siswa melakukan kegiatan, menyediakan alat/bahan perlu disediakan sesuai dengan kebutuhan siswa dalam melaksanakan kegiatan, siswa menyusun, memproses, mengorganisir, dan menganalisis data. Dalam hal ini bimbingan guru dapat diberikan sejauh yang diperlukan saja. Bimbingan ini sebaiknya mengarahkan siswa untuk melangkah kearah yang hendak dituju, melalui pertanyaanpertanyaan, atau LKS, melakukan penyelidikan/percobaan untuk menemukan konsepkonsep atau prinsip-prinsip yang telah ditetapkan, siswa menyusun konjektur (prakiraan) dari hasil analisis yang dilakukannya, konjektor yang telah dibuat oleh siswa tersebut di atas diperiksa oleh guru. Hal ini penting dilakukan untuk meyakinkan kebenaran prakiraan siswa, sehingga akan menuju arah yang hendak dicapai, setelah siswa menemukan apa yang dicari, hendaknya guru menyediakan soal latihan atau soal tambahan untuk memeriksa apakah hasil penemuan itu benar, perlu dikembangkan pertanyaan-pertanyaan yang bersifat terbuka, yang mengarah pada kegiatan yang dilakukan siswa, ada catatan guru yang meliputi penjelasan tentang hal-hal yang sulit dan factorfaktor yang dapat mempengaruhi terutama kalau penyelidikan mengalami kegagalan atau tak berjalan sebagaimana mestinya.

Pembelajaran dengan discovery mempunyai banyak kelebihan sebagai berikut: strategi pembelajaran menjadi berubah dari yang bersifat penyajian informasi oleh guru kepada siswa sebagai penerima informasi yang baik tetapi proses mentalnya berkadar rendah, menjadi pengajaran yang menekankan kepada proses pengolahan informasi di mana siswa yang aktif mencari dan mengolah sendiri informasi yang kadar proses menyalnya lebih tinggi atau lebih banyak, mendorong siswa untuk berpikir analisis kritis dan bekerja atas anisiatifnya sendiri, siswa akan mengerti konsep-konsep dasar atau ide lebih baik, membantu siswa dalam menggunakan ingatan dan dalam rangka transfer kepada situasi-situasi proses belajar yang baru, memungkinkan siswa belajar dengan memanfaatkan berbagai jenis sumber belajar yang tidak hanya menjadiakn guru sebagai satu-satunya sumber belajar, metode ini dapat memperkaya dan memperdalam materi yang dipelajari sehingga retensinya (tahan lama dalam ingatan) menjadi lebih baik [8].

Peran utama guru dalam menciptakan kondisi pembelajaran discovery adalah sebagai berikut: motivator, yang memberi rangsangan supaya siswa aktif dan gairah berpikir, fasilitator, yang menunjukkan jalan keluar jika ada hambatan dalam proses berpikir siswa, untuk menyadarkan siswa dari kekeliruan yang mereka perbuat dan memberi keyakinan pada diri sendiri, administrator, yang bertanggung jawas terhadap seluruh kegiatan di dalam kelas, pengarah, yang memimpin arus kegiatan berpikir siswa pada tujuan yang diharapkan, manager, yang mengelola sumber belajar, waktu, dan organisasi kelas, rewarder, yang memberi penghargaan pada prestasi yang dicapai dalam rangka peningkatan semangat heuristic pada siswa [11].

Pengajaran dengan discovery mempunyai sintaks aliran kegiatan yaitu menentukan tujuan pengajaran, pengantar singkat tentang konten dan prosedur, membentuk kelompok, klarifikasi tujuan, kerja individual, laporan pada kelompok, diskusi kelompok, laporan kelompok, diskusi kelas, rangkuman dan tindak lanjut. Melalui sintaks tersebut diharapkan kegiatan pembelajaran yang dilakukan siswa menjadi lebih berperan aktif dan hasil belajar menjadi lebih baik.

Hasil belajar merupakan penilaian pendidikan tentang perkembangan dan kemajuan murid yang berkenaan dengan penguasaan bahan pelajaran yang disajikan kepada mereka serta nilainilai yang terdapat dalam kurikulum [12]. Hasil belajar yang baik tidak dicapai seseorang selama tidak melakukan kegiatan belajar. Ada dua faktor yang mempengaruhi hasil belajar adalah faktor endogen dan eksogen. Faktor endogen yaitu faktor yang berasal dari dalam diri seseorang meliputi faktor biologi (jasmaniah) dan faktor rohani (psikologis). Sedangkan faktor eksogen adalah faktor yang berasal dari luar diri seseorang yang meliputi faktor lingkungan keluarga, sekolah dan masyarakat[13]. Pendekatan, metode, teknik dan media juga merupakan faktor eksogen yang mempengaruhi hasil belajar.

Hasil belajar akan meningkat dengan usaha memaksimalkan fungsi masing-masing faktor di atas. Ada beberapa langkah yang dapat dilakukan dalam pembelajaran klasikal yang mempengaruhi hasil belajar siswa yaitu dalam mengajar hendaknya guru menggunakan pendekatan, strategi yang mengaktifkan peran siswa salah satunya adalah strategi discovey[14]. Tujuan penelitian ini adalah menerapkan strategi pembelajaran discovery dalam rangka meningkatkan hasil belajar siswa pada mata pelajaran IPA Biologi kelas VII-5 SMPN 4 Mataram.

\section{METODE PENELITIAN}

Penelitian ini dilakukan di SMPN 4 Mataram pada kelas VII-5 dengan jumlah siswa 34 orang terdiri dari 14 orang laki-laki dan 18 orang perempuan. 
Faktor-faktor yang diteliti adalah faktor siswa yakni hasil belajar siswa yang diajarkan dengan strategi pembelajaran discovery dan faktor guru mengenai kemampuan guru melaksanakan pembelajaran dengan strategi pembelajaran discovery.

Jenis penelitian yang dilaksanakan adalah pnelitian tindakan kelas (Classroom Action Research) [12]. Penelitian tindakan kelas ini bersifat kerjasama (kolaboratif) dengan teman sejawat. Penelitian ini dilaksanakan dengan tahapan sebagai berikut.

\section{Siklus I}

a. Tahap Perencanaan (Planning)

Pada tahap ini kegiatan-kegiatan yang dilakukan meliputi:

1) Membuat skenario pembelajaran dengan menerapkan strategi pembelajaran discovery.

2) Menyiapkan media alat dan bahan yang dibutuhkan dalam pembelajaran.

3) Menyusun lembar observasi untuk menilai situasi belajar mengajar selama pembelajaran berlangsung.

4) Menyusun tes hasil belajar.

5) Menyiapkan daftar hadir siswa dan observer.

b. Tahap Tindakan

Pada tahap ini guru dan siswa melaksanaakan kegiatan pembelajaran di dalam kelas sesuai dengan rencana yang telah dituangkan dalam skenario pembelajaran. Kegiatan yang dilakukan pada tahap ini adalah sebagai berikut:

a. Memberikan motivasi kepada siswa tentang pentingnya ppenuasaan materi pelajaran ini.

b. Memberikan apersepsi untuk mengetahui kesiapan siswa atau mengarahkan siswa ke materi pelajaran yang akan dibahas.

c. Melaksanakan tahapan-tahapan pembelajaran sesuai dengan rencana pelaksanaan pembelajaran. Secara umum tahapan pembelajaran pada tiap siklus dilakukan dengan cara:

1. Menentukan tujuan pembelajaran.

2. Membagi siswa menjadi beberapa kelompok (6 kelompok).

3. Membagi LKS/petunjuk praktikum pada masing-masing kelompok.

4. Membimbing dan melakaukn pemantauan siswa dalam bekerja.

5. Masing-masing kelompok mempresentasikan hasil temuannya di depan kelas.

6. Membuat laporan kelompok.
7. Diskusi kelas dengan bersama-sama siswa membuat rangkuman atau kesimpulan dari tugas-tugas.

d. Mengidentifikasi kesulitan-kesulitan yang dihadapi siswa dan guru selama proses belajar mengajar berlangsung.

c. Tahap Observasi (Observation)

a. Mengamati aktivitas guru dan mencatat semua hambatan, kesulitan yang dialami siswa dan guru selama pembelajaran. Aktivitas guru direkam dengan lembar observasi yang dilakukan oleh observer. Hasil dari kegiatan observasi pembelajaran digunakan untuk memperbaiki pelaksanaan tindakan pada siklus berikutnya.

b. Mengevaluasi pencapaian hasil belajar dengan memberikan tes pada tiap akhir siklus.

d. Tahap Refleksi (Reflection)

Kegiatan yang dilakukan pada tahap ini adalah:

a. Bersama-sama dengan anggota tim menganalisa hasil evaluasi, hasil observasi dan temuan lain pada saat berlangsungnya pembelajaran pada pelaksanaan tindakan I.

b. Mencari alternative pemecahan dari temuan-temuan tersebut sebagai bahan masukan dalam perencanaan tindakan pada siklus berikutnya (siklus II).

c. Tindakan pada siklus II ditentukan berdasarkan hasil refleksi pada siklus I, tindakan pada siklus III ditentukan berdasarkan hasil refleksi pada siklus II.

\section{Siklus II}

Pelaksanaan dan langkah siklus II sama dengan siklus I yang merupakan penyempurnaanpenyempurnaan dari siklus sebelumnya.

Cara pengumpulan data sebagai berikut :

a. Data tentang kemampuan guru dalam melaksanakan proses pembelajaran dengan strategi discovery menggunakan lembar observasi guru.

b. Data hasil belajar dengan lembar tes

Data dianalisis secara kualitatif dengan melihat penyempurnaan-penyempurnaan pada tiap siklus pembelajaran:

1. Data tentang kemampuan guru menerapkan strategi pembelajaran discovery dianalisis secara kualitatif (skor 5 = sangat baik, skor $4=$ baik, skor $3=$ cukup, skor 2 = kurang baik, skor $1=$ sangat kurang). Adapun rentang nilai yang digunakan untuk mengetahui kriteria keefektifan aplikasi pembelajaran 
discovery ini digunakan kriteria sebagai berikut:

Tabel 2. Skor dan kriteria penilaian keefektifan aplikasi pembelajaran discovery.

\begin{tabular}{lll}
\hline No. & Skor total & Kriteria \\
\hline 1 & $0,00-2,99$ & Kurang memuaskan \\
2 & $3,00-3,99$ & Memuaskan \\
3 & $4,00-5,00$ & Sangat memuaskan \\
\hline
\end{tabular}

2. Data hasil belajar siswa dilihat dari kemampuan mengerjakan tes tertulis.

Indikator kinerja yang dijadikan sebagai dasar untuk mengukur tingkat keberhasilan pembelajaran yang menggunakan strategi pembelajaran discovery dalam penelitian ini adalah:

a. Hasil belajar siswa meningkat dari siklus sebelumnya dan mencapai kriteria ketuntasan minimal (KKM). Tuntas secara individu jika seorang siswa memperoleh nilai $\geq 60$ sesuai KKM. Tuntas secara klasikal jika $\geq 85 \%$ siswa memperoleh nilai $\geq 60$.

b. Aktivitas guru mencapai rata-rata skor $\geq$ 4,5 dalam menerapkan strategi pembelajaran discovery.

\section{HASIL DAN PEMBAHASAN}

A. Hasil Penelitian

1. Deskripsi Hasil Penelitian Siklus I

a. Perencanaan

Pada tahap ini dilakukan beberapa perencanaan yang meliputi pembuatan: skenario pembelajaran, rencana pelaksanaan pembelajaran, lembar kerja siswa, soal evaluasi, kunci jawaban, dan lembar observasi.

b. Pelaksanaan

Proses belajar mengajar pada siklus I dilaksanakan sesuai dengan jadwal mata pelajaran IPA Biologi di sekolah selama $3 \mathrm{x}$ 40' pokok bahasan keanekaragaman tumbuhan. Pada siklus ini dilakukan observasi kegiatan proses belajar mengajar dengan strategi pembelajaran discovery. Hasil pengamatan observasi tentang kekurangankekurangan tindakan akan diperbaiki pada siklus selanjutnya.

Pada akhir pembelajaran diadakan evaluasi untuk melihat sejauh mana penguasaan siswa terhadap materi yang telah disampaikan. Segala kekurangan-kekurangan yang terjadi pada siklus I ini direvisi dan direfleksi kembali untuk melanjutkan tindakan pada siklus berikutnya.

c. Observasi dan Evaluasi

1. Hasil Observasi Guru
Berdasarkan hasil analisis lembar observasi diperoleh data sebagai berikut:

Tabel 3: Data aktivitas guru

\begin{tabular}{lll}
\hline Analisis Hasil & Jumlah & Kategori \\
\hline Jumlah total skor & 27 & Memuaskan \\
$\begin{array}{l}\text { Rata-rata skor } \\
\begin{array}{l}\text { Skor } \\
\text { ideal/Indikator }\end{array}\end{array}$ & 3,85 & \\
kinerja & $\geq 4,5$ & $\begin{array}{l}\text { Sangat } \\
\text { memuaskan }\end{array}$ \\
\hline
\end{tabular}

Berdasarkan hasil analisis lembar observasi aktivitas guru di atas jumlah skor total 27 dengan kategori memuaskan. Kekurangankekurangan yang muncul pada siklus I adalah sebagai berikut:

a. Guru belum maksimal dalam menggunakan strategi pembelajaran discovery.

b. Guru masih terfokus pada kelompok-kelompok tertentu.

c. Kurang maksimal dalam memeriksa laporan yang dikerjakan kelompok.

d. Belum maksimal dalam membimbing siswa dalam membuat rangkuman pelajaran.

e. Suasana kelas masih kurang kondusif, siswa masih ada yang bermain-main.

2. Hasil Evaluasi belajar siswa

Setelah melakukan proses belajar mengajar selanjutnya guru memberikan soalsoal evaluasi kepada siswa. Bentuk soal evaluasi adalah soal berbentuk easy untuk dikerjakan secara individu. Masing-masing siswa dapat satu lembar soal. Melalui analisis evaluasi belajar nilai rata-rata siswa dan ketuntasan belajar siswa dapat dilihat pada tabel 4.

Tabel 4: Data Hasil Evaluasi Belajar Siswa Siklus I Kelas VII-5 SMPN 4 Mataram

\begin{tabular}{clc}
\hline No. & Uraian & Jumlah \\
\hline 1 & Banyak siswa & 32 \\
2 & Skor tertinggi & 100 \\
3 & Skor terendah & 31 \\
4 & Skor total & 26 \\
5 & Nilai rata-rata & 71,8 \\
6 & Banyak siswa yang & 21 \\
& tuntas & \\
7 & Persentase ketuntasan & $66 \%$ \\
8 & klasikal (\%) & $\geq 85 \%$ \\
\hline
\end{tabular}

Dari tabel 4 di atas dapat dilihat bahwa persentase ketuntasan belajar klasikal pada siklus I belum mencapai standar minimal $85 \%$. Ada 11 orang siswa yang tidak tuntas secara individu pada siklus I ini. Pada pertemuan siklus berikutnya akan diberikan bimbingan dan perhatian khusus di kelas ketika proses belajar mengajar berlangsung di samping itu 
juga guru memberikan upaya dalam mengendalikan kendala yang dihadapi atau penyebab lainyang dialami oleh 11 orang siswa tersebut. Karena penelitian pada siklus I belum mencapai ketuntasan belajar klasikal, maka peneliti merencanakan tindakan perbaikan pada siklus II.

\section{d. Refleksi}

Prosentase ketuntasan belajar siswa $66 \%$ ini menunjukkan bahwa ketuntasan dilihat dari hasil evaluasi pada siklus I masih belum mencapai hasil yang diharapkan. Adapun kekurangan-kekurangan yang ditemukan pada siklus ini akan diperbaiki pada siklus kedua diantaranya:

1. Guru masih terfokus pada kelompok-kelompok tertentu dan kelompok yang lain masih bersifat kurang aktif.

2. Guru masih kurang dalam memberikan motivasi kepada siswa yang kurang aktif untuk berani maju mempresentasikan hasil penemuannya di depan kelas.

3. Antusias siswa dalam pembelajaran masih kurang karena masih banyak siswa yang terpengaruh situasi di dalam kelas.

4. Pada saat mengerjakan LKS masih ada kelompok yang belum paham dengan isi LKS.

\section{Deskripsi Hasil Penelitian Siklus II}

\section{a. Perencanaan}

Pada tahap ini dilakukn beberapa perencanaan yang meliputi pembuatan: skenario pembelajaran, Rencana Pelaksanaan Pembelajaran, Lembar Kerja Siswa, Soal Evaluasi, Kunci Jawaban, dan Lembar Observasi.

\section{b. Pelaksanaan}

Proses belajar mengajar pada siklus II dengan materi yang dibahas adalah keanekaragaman hewan dengan 3 x 40'. Pelaksanaan tindakan disesuaikan dengan skenario pembelajaran yang telah dibuat oleh peneliti. Pada siklus ini juga dilakukan pengamatan oleh observer dengan menggunakan lembar observasi. Siswa yang belum mencapai ketuntasan belajar sebanyak 11 orang pada siklus I diberikan bimbingan pada saat berlangsungnya proses belajar mengajar di kelas.

Selanjutnya pada akhir pembelajaran diadakan evaluasi untuk melihat sejauhmana penguasaan siswa terhadap materi yang telah disampaikan.

\section{c. Observasi dan Evaluasi \\ 1) Hasil Observasi}

Berdasarkan hasil analisis lembar observasi diperoleh data sebagai berikut:

Tabel 5: Hasil analisis lembar observasi penggunaan strategi pembelajaran discovery pada siklus II

\begin{tabular}{lll}
\hline \multicolumn{1}{c}{$\begin{array}{c}\text { Analisis } \\
\text { Hasil }\end{array}$} & Jumlah & \multicolumn{1}{c}{ Kategori } \\
\hline Jumlah total skor & 34 & Sangat \\
Rata-rata skor & 4,86 & memuaskan \\
Skor ideal & $\geq 4,5$ & Sangat \\
& & memuaskan \\
\hline
\end{tabular}

Berdasarkan hasil analisis lembar observasi aktivitas guru di atas jumlah skor total 34 dengan kategori sangat memuaskan. Kekurangankekurangan yang muncul pada siklus II relatif sedikit yaitu adanya siswa yang kurang fokus pada saat presentasi hasil penemuannya.

\section{2) Hasil Evaluasi}

Setelah melakukan proses belajar mengajar selanjutnya guru memberikan soal-soal evaluasi kepada siswa. Evaluasi berlangsung setengah jam. Bentuk soal evaluasi adalah soal bentuk Esay untuk dikerjakan secara individu. Masing-masing siswa dapat satu lembar soal. Melalui analisis belajar nilai rata-rata siswa dan ketuntasan belajar siswa dapat dilihat pada tabel 6 berikut:

Tabel 6: Data Hasil Evaluasi Belajar Siswa Siklus

\begin{tabular}{clc} 
II & & \\
\hline No. & Keterangan & Jumlah \\
\hline 1 & Banyak siswa & 32 \\
2 & Skor tertinggi & 100 \\
3 & Skor terendah & 0 \\
4 & Skor total & 2631 \\
5 & Nilai rata-rata & 82,2 \\
6 & Banyak siswa yang tuntas & 29 \\
7 & Persentase ketuntasan klasikal & $90 \%$ \\
8 & Indikator kinerja & $\geq 85 \%$ \\
\hline
\end{tabular}

Tabel 7: Data persentase pencapaian variable harapan dan tindakan per siklus

\begin{tabular}{llllll}
\hline No. & Siklus & $\begin{array}{l}\text { Persentase } \\
\text { Variabel } \\
\text { Harapan }\end{array}$ & $\begin{array}{l}\text { Persentase } \\
\text { Indikator }\end{array}$ & $\begin{array}{l}\text { Persentase } \\
\text { Variabel } \\
\text { Tindakan }\end{array}$ & $\begin{array}{l}\text { Indikator } \\
\text { Kinerja }\end{array}$ \\
\hline 1 & I & $66 \%$ & $\geq 85 \%$ & 3,85 & $\geq 4,5$ \\
2 & II & $90 \%$ & $\geq 85 \%$ & 4,86 & $\geq 4,5$ \\
\hline
\end{tabular}

Berdasarkan hasil analisis pada tabel 6 di atas terlihat bahwa ketuntasan belajar secara klasikal
$90 \%$, sudah lebih dari standar ketuntasan klasikal $85 \%$, ini berarti proses pendekatan pada siklus II 
sudah dikatakan berhasil atau tuntas. Walaupun hasilnya telah tuntas tetapi untuk siswa yang belum tuntas masih diberikan beberapa latihan soal yang terkait dengan materi yang telah diajarkan yang slah satu seperti remedial, latihan secara individu dan bimbingan khusus sehingga siswa mencapai ketuntasan belajar ideal.

\section{d. Refleksi}

Dilihat dari hasil yang diperoleh pada siklus II dikatakan telah tuntas karena telah mencapai ketuntasan belajar yang diharapkan $85 \%$ [5].

Dengan demikian proses belajar mengajar dengan menerapkan strategi pembelajaran discovery dapat meningkatkan hasil belajar siswa kelas VII-5 SMPN 4 Mataram.

\section{Pembahasan}

Berdasarkan hasil analisis data tiap-tiap siklus, terlihat bahwa hasil dari siklus ke siklus mengalami peningkatan. Terlihat seperti tabel 7 di atas ini pada siklus I menunjukkan bahwa bahwa persentase ketuntasan $66 \%$.

Ini berarti ketuntasan belajar siswa belum tercapai sesuai dengan ketuntasan belajar menurut standar yang telah ditetapkan. Hal ini disebabkan oleh kurangnya kesiapan siswa dlam mengikuti proses pembelajaran dengan menerapkan strategi pembelajaran disvovery yang dikarenakan strategi pembelajaran ini merupakan strategi pembelajaran beru yang diterapkan guru, perhatian siswa dalam kegiatan pembelajaran belum terfokus, saat diskusi hasil temuan siswa masih banyak yang belum mau menanggapi pendapat atau temuan dari temannya dan siswa belum bisa membuat kesimpulan dari hasil temuan dan diskusi sehingga tingkat penyerapan siswa terhadap materi yang diberikan belum optimal.

Berdasarkan hasil tersebut maka untuk mengatasi banyaknya kekurangan-kekurangan selama pelaksanaan siklus I guru melakukan perbaikan-perbaikan dalam pembelajaran pada siswa berikutnya dan meningkatkan hal-hal yang dianggap kurang. Untuk itu guru berupaya untuk meningkatkan ketertiban siswa dan membangkitkan respon siswa dalam proses pembelajaran sesuai dengan refleksi pada siklus I, maka pada siklus II dilakukan tindakan yang merupakan penyempurnaan dan perbaikan terhadap kekurangan-kekurangan yang muncul pada siklus I.

Berdasarkan hasil analisis pada siklus II menunjukkan bahwa nilai rata-rata sebesar 82,2 dengan persentase ketuntasan belajar siswa sebesar $90 \%$. Ini berarti ketuntasan belajar siswa telah sesuai dengan ketuntasan yang telah ditetapkan. Hal ini disebabkan karena kesiapan siswa dalam mengikuti proses pembelajaran dengan menerapkan pembelajaran discovery sudah sangat baik, suasana pembelajaran berjalan dengan baik.
Perhatian siswa sudah mulai terfokus, saat diskusi siswa sudah banyak yang mau menanggapi pendapat dari temannya dan siswa sudah mulai bisa membuat kesimpulan dari hasil temuan dan diskusi. Karena tujuan dari penelitian sudah tercapai dan kegiatan pembelajaran sesuai dengan rencana dan harapan, maka siklus penelitian diakhiri.

Sesuai dengan pendapat ahli menyebutkan bahwa pembelajaran dengan discovery membuat kemampuan siswa mengingat pelajaran lebih lama sehingga hasil belajar siswa lebih baik [4].

\section{SIMPULAN DAN SARAN}

\section{A. Simpulan}

Hasil penelitian menunjukkan bahwa hasil belajar siswa pada siklus I adalah rata-rata kelas 71,8. Siswa yang memenuhi ketuntasan belajar individu sebanyak 21 siswa dari 32 siswa, sehingga presentase ketuntasannya mencapai $66 \%$. Rata-rata skor pelaksanaan pembelajaran dengan strategi discovery 3,85 (memuaskan). Pelaksanaan evaluasi pada siklus II diperoleh data hasil belajar siswa dengan rata-rata 82,2. Presentase ketuntasan belajar secara klasikal mencapai 90\%. Rata-rata skor pelaksanaan pembelajaran dengan strategi discovery 4,86 (sangat memuaskan). Dari hasil penelitian dan pembahasan dapat disimpulkan bahwa penerapan strategi pembelajaran discovery dapat meningkatkan hasil belajar IPA Biologi siswa kelas VII-5 SMPN 4 Mataram.

\section{DAFTAR PUSTAKA}

[1] Anonym. 2003. Undang-Undang no. 20 Tahun 2003 tentang Sistem Pendidikan Nasional. Jakarta.

[2] Wina,. 2008. Strategi Pembelajaran; Berorientasi Standar Proses Pendidikan. Jakarta: Kencana Prenada Media Group.

[3] Mahyaeny., 2015, Penerapan model pembelajaran kooperatif tipe tps (think pair share) untuk meningkatkan aktivitas belajar ipa biologi kelas VII. 5 SMPN 4 Mataram. Jurnal Pijar Mipa, 10(2).

[4] Nuzuli, A. 2007. Penggunaan Strategi Discovery untuk Meningkatkan Hasil Belajar Biologi di SMPN 2 Jonggat. Skripsi. Mataram: IKIP Mataram.

[5] Sumiadi, R., Jekti, D. S. D., \& Jamaluddin, J. (2015). Pengembangan perangkat pembelajaran berbasis pendekatan saintifik model guided discovery dan efetivitasnya terhadap kemampuan berpikir kreatif siswa sma negeri 1 bayan. Jurnal pijar Mipa, 10(2). 
[6] Zakrah, Z., \& Lestari, N. (2015). Pengaruh strategi pembelajaran discovery terhadap kemampuan berpikir kritis siswa pada mata pelajaran ipa kelas viii di smpn 3 gunungsari tahun ajaran 2014/2015. Jurnal pijar MIPA, $10(2)$.

[7] Sukamti. 2007. Penerapan Metode DiscoveryInquiry dalam Pengajaran IPA di Sekolah Dasar. Laporan Penelitian. Malang: Universitas Negeri Malang.

[8] Zainul. 2005. Tes dan Assesmen. Jakarta: Universitas Terbuka.

[9] Hamalik, O. 2001. Pendekatan Baru Belajar Strategi Belajar Mengajar Berdasarkan CBSA. Bandung: Sinar Baru Algensindo.
[10] Sutrisno, J. 2008. Pengaruh Metode Pembelajaran Discovery Inquiry dalam Belajar Sains terhadap Motivasi Belajar Siswa. http://www.erlangga.co.id. Diakses pada tanggal 18 Oktober 2008.

[11] Djamarah. 2002. Berbagai Pendekatan Pembelajaran. Jakarta: Rineka Cipta.

[12] Wibawa, B. 2004. Penelitian Tindakan Kelas. Jakarta: Depdiknas

[13] Ibrahim. 2002. Belajar Konstruktivisme, Model Pelatihan Berbasis Kompetensi Guru Mata Pelajaran IPA. Jakarta: Dikdasmen.

[14] Ahmadi. 1997. Strategi Belajar Mengajar. Bandung: CV Pusaka Setia. 